\title{
Economics, Economists and Public Policy in Australia
}

\author{
Gary Banks ${ }^{1}$
}

The topic for this Symposium, 'Does Australian public policy get the economics it deserves?' has been partitioned into two questions. One asks whether public policy gets the economics it needs. The other, no doubt inspired by Alexis de Tocqueville's famous observation about people and their elected governments, is whether Australian economics gets the public policy it deserves.

My answer to the first question came readily: in short, no - or at least not often. The answer to the de Tocquevillian one required reflection, however; not only about the state of public policy in Australia, but also about that of Australian economics. And my answer to that one is: I'm not sure!

Much could be said from both perspectives. In setting the scene, I will confine myself to some observations about what might be called the 'contextual' influences on public policy and its use of economics (or information generally).

My key message, which should not be surprising, is that systems determine outcomes. Public policy will only get the economics it needs, or indeed that society needs, if the processes, the institutions and the individuals responsible for developing it are receptive to good economics, and responsive to it. Equally, I'd argue that how 'deserving' Australian economics or economists might be - in other words, the health of the supply-side - is not independent of the incentives generated by the policy system - the demand side.

\section{What Sort of 'Economics'?}

Now the term 'needs' might suggest that it is challenging to discover and apply this necessary economics. In some areas of public policy that may indeed be so, but in many cases the sort of economics needed to inform policy decisions isn't very complicated or sophisticated.

Much public policy could go a long way with a few basic principles or precepts. I'll just mention four.

1 Productivity Commission. The paper is a revised version of the opening address to the 40th Australian Conference of Economists Symposium, Does Australian public policy get the economics it deserves?, 14 July 2011, Canberra. 
- The most basic is that there is no 'free lunch'. Economies have finite resources, which means scarcity and therefore opportunity costs to their use.

- A second principle is that prices matter in allocating scarce resources to where they can do the most good for an economy and society. Market prices signal both production costs and people's valuations.

- Third, the responsiveness of people to relative prices - and to changes in relative prices - will vary, but the lower the price, generally the greater is demand: as economists put it, 'demand curves slope down'.

- Fourth, no part of an economy is an island. What happens in one industry, sector or region affects and is affected by what happens in others.

One might say that all of these are just common sense. But we see policy proposals and decisions that violate those principles almost on a daily basis. We see policy proposals and decisions that seem to assume that there is no such thing as scarcity; that there are no substitution or income effects; and that there is no interdependence within the economy. Decisions based on such anti-economic thinking are not just a relic of the bygone era of 'protection all round'.

The reality is that even the most basic economic concepts are not intuitive or self-evident to the average person (the 'man on the Clapham Bus', as my Welsh friend Steve puts it). Indeed, some economic principles and tools can be forgotten or lost even by people with economics training.

The foreword to my favourite economics primer, by Alchian and Allen (1969), cites Alain Enthoven, the Assistant Secretary of the US Defence Department, on the rationale for an economics $\mathrm{PhD}$, as follows: 'Many economists don't believe what they've learned until they've acquired a vested interest in marginal analysis.' (The Defence Department was a pioneer of cost-benefit analysis in the USA - contrasting somewhat with our own.)

We also need to acknowledge that art as well as science is called for in applying economic principles and frameworks to real-world problems: in relation to understanding the exact nature of those problems, assessing what will work best, and identifying the relevant impacts, given that there will be many influences at work. Policymakers must operate in what economists refer to as a 'second best' world. This calls for more than the textbook when contemplating additional government interventions. It calls for judgement; it calls for experience, and indeed it calls for incentives for decision-makers to make the best call (a point to which I'll return). And, even when these conditions are satisfied, we can never be certain of the outcome. Good policy is not a one-off event: it requires ongoing review, and amendment in the light of experience (Banks 2010). 


\section{What Sort of 'Process'?}

That is why processes and institutions can be crucial to whether and how effectively economics is brought to bear on public policy. Good policy, and indeed having good economics behind it, requires good process. It may not be sufficient, but it is certainly necessary.

At face value, the requirements for good process in policymaking are not that demanding. The essentials are well described by the legendary American economist Frank H. Knight, in his book Intelligence and Democratic Action (Knight 1960). Knight sets out the conditions for what he describes as 'intelligent' - what we'd call today 'well-informed' — political decision-making.

According to Knight, 'if policy is to have a reasonable chance of improving a situation, certain steps need to be followed'. The first of these is understanding what will happen without intervention and why. The second step is to decide what interventions are feasible; the third to assess their consequences; and the fourth to rank the alternatives, ultimately reflecting the value judgements of political representatives.

\section{Easily Said}

That sequence for 'intelligent' policymaking anticipated the 'impact assessment' framework for regulation-making that has since been embraced by many OECD countries, including Australia. Yet, we've struggled to inculcate such an approach within government, notwithstanding that these provisions commenced some 25 years ago. Often only lip-service is paid, or assessments undertaken after a policy decision has already effectively been made. Why is that so?

I've become fond of quoting the observation by Maynard Keynes that 'There's nothing a government hates more than to be well informed. It makes the process of arriving at decisions much more complicated and difficult' (Moggridge and Johnson 1982). He might have added that it also makes the process more inconvenient, in circumstances where governments are keen to follow a course that good economics might not support.

The reality is that there is generally more vocal support within the electorate for bad policy than for good, reflecting well-known asymmetries in the impacts of policy and reform within an economy and community. We also often see political deal-making acquiring a life of its own within the Parliament, taking a policy in unfortunate directions, regardless of how good the starting point might have been. 
It is therefore to be celebrated that in the 1980s and '90s substantial headway was made against these forces, resulting in an important series of economic reforms from which we are still benefiting today. We've also seen those obstacles being overcome in some individual policy actions since then, but not a lot.

The principal success factors in what the OECD now calls the Australian Model of structural reform, arguably boil down to two: one is having solid research to identify the problems and their causes, and thereby to establish the case for reforms that would actually make things better. The second is the effective communication of this to the public, to build support based on the understanding that a policy that is being contemplated will indeed make people better off overall. ${ }^{2}$

\section{How 'Deserving' are Australian Economists?}

As indicated, the existence of good process or good policymaking systems is also relevant to the second question - whether Australian economics gets the public policy it deserves. I take this to mean the contribution of Australian economists, rather than some special Australian branch of economic theory. It is rather topical to be talking about this just now, given the Leader of the Opposition's recent critical comment about the profession in Australia.

How deserving economists might be obviously depends on the quality of their contribution. However, I'd argue again that this is not independent from how demanding or 'receptive' the policymaking process itself has been. This has fluctuated considerably over time, but has arguably been trending down over the past several years. ${ }^{3}$

\footnotetext{
2 A referee has remarked that this assessment neglects 'the lesson of political economy that, if you do not compensate them, the relatively few losers, who have relatively large stakes, can derail a policy' and notes that 'compensation also provides a crude test of Pareto superiority'. While compensation has indeed played a role in some areas (notably the GST), it has generally been a subordinate one, having more to do with implementation and transition than gaining acceptance of the need for reform itself. Compensation has only been explicitly addressed where a reform was seen to violate (de facto) property rights (for example, dairy deregulation, taxis) or to be unfair in its incidence. That said, transfers have been implicit in the gradualist approach that has typified some major Australian reforms (notably tariff liberalisation) and also in the 'grandfather clauses' used in tax reform and the 'no-disadvantage test' in labour-market deregulation. And the National Competition Policy was underpinned by 'competition payments' from the Commonwealth to State and Territory Governments, even though the latter were individually winners overall without it. (For a discussion of the role of compensation and adjustment assistance in structural policy reform, see PC 2001.) 3 Henry Ergas, in commenting on this presentation, raised whether this may be due to the lower opportunity cost of inefficiency in good times than in bad. He notes that our 'golden ages' of economics were times of economic crisis - the 1930s and 1980s - observing that strong terms of trade have been bad for Australian economics and, by extension, economic policy.
} 
Australian economists have been very influential in relation to public policy and reform over the years. The question is whether they are less so today than in the past. There are four main sources of economic advice or analysis that I'll go through in considering this.

\section{The academics}

The first is academia. Academic economists in Australia have played an important, indeed crucial, role in laying foundations of theory and research on which others, including economists in government, have depended.

Traditionally, academic economists were attuned to the particular policy needs of this country. Australian academics have produced seminal work in such areas as trade theory and protection measurement, agricultural economics, open-economy macroeconomics and CGE modelling.

Australian academics have also been directly engaged in the policymaking process over the years, including through stints within government itself. They have thereby had a significant impact not only through their writings, but also through more direct involvement in the policy process. That seems less evident today and may reflect a more general malaise in academic economics.

Observing from the 'outside', there appears to have been a loss of mainstream economics within many of our universities, both in teaching and research. Economics seems to have gone in two directions - a softer commerce-related direction, and a highly 'mathematical' one.

There is a question as to whether that has contributed to 'economics' becoming a less attractive proposition for many young potential students. We've certainly seen a drop-off in the number of economics graduates and in the number of young people choosing to study economics proper.

There is also a question as to whether enough academic economists in Australia are applying themselves to the policy issues of the day. If we think about the burning policy debates in relation to social and environmental issues, how prevalent are academic economists in these? Only a few come to mind as being active public contributors on such topics as education, health, welfare, migration and, even that most 'wicked' contemporary policy challenge of all, Australia's response to global warming. ${ }^{4}$

4 One of the commentators for this paper has explained this in terms of the incentives facing academics under 'managerialism' within universities, in which 'Heads of Schools are given little scope to reward academics who contribute to public policy'. Another commentator notes the 'emphasis put on work models, performance indicators and possibly even on what might be termed "political correctness". A third cites in particular "the ERA journal-ranking exercise' as influencing what academics do. And a fourth speculates whether 'the rising proportion of non-Australian origin academics is playing any role', noting their 'lack of context and therefore lack of confidence in adding their voices to public debate'. 
Another issue is whether the long-standing existence of different 'camps' and dissenting views within the profession may have weakened its collective influence. Are we fuelling the public's perception of economics as a 'two-handed' discipline, one that rarely ends up coming to decisive conclusions or policy solutions to real-world problems? Of course that would not be a new perception: recall George Bernard Shaw's quip that 'if economists were laid end to end they would not reach a conclusion'.

You may also recall comments last year by then Treasury Secretary Ken Henry indicating some frustration that the Government's major policy initiatives on mining taxation and carbon abatement at that time were not receiving stronger support from the economics fraternity, given that the core economic principles in those areas - related to economic rent and market-based mechanisms - are ones that economists would generally all accept at some level. This suggests that policy in Australia may not be getting the economists it deserves.

However, it is not at all clear that the dissenting views of some of the leading protagonists have been about matters of little consequence. For example, while 'economic rent' is a well-defined concept in theory, its identification and extraction in practice through government taxation - such as to avoid impacts on production or investment decisions - are very difficult, if not impossible, and will depend crucially on the detailed policy design. Equally, while marketbased mechanisms have superior economic credentials for addressing pollution, and thus also in principle for reducing carbon dioxide emissions, their form, scope and timing are all germane to their efficacy and efficiency in practice.

Further, returning to one of my themes, it is questionable whether there was sufficient opportunity for such differences to be debated (in the Knightian sense) before the policies in question were fully formed. And, as we have seen, if there is no great effort made to attain some resolution among economists and other experts early on, later resolution among politicians and key interests may well generate outcomes that would satisfy no economist.

\section{The bureaucrats}

A second key source of economic advice is the bureaucracy. This has traditionally been a stronghold of economic thinking and application. During the reform era of the 1980s and early '90s, several 'practising' economists headed key departments of State. Economists were also commonly key advisors in ministers' offices.

At the departmental level, I think Treasury is now the last refuge of economists - in terms of a working environment in which economic thinking is central and lawyers and publicists now greatly outweigh economists among 'political staffers'. 
Beyond the departments, there is the Reserve Bank, which does excellent research and brings a measure of contestability to macroeconomic policy debates. And there are those research agencies that are adjuncts to particular departments, though these appear to have become less independent and influential over time.

Finally, I shouldn't omit my own organisation, the Productivity Commission, which continues to apply economics and evidence to a range of key policy questions through its public inquiries and other studies.

The scope of the Commission's work has widened considerably over time, extending well beyond its predecessors' staple fare of industry assistance and economic infrastructure, to important areas of social and environmental policy. There are a number of reasons for this. I'd like to think that a key one is greater recognition of the value of the Commission's evidence-based and consultative approach to policy development on the 'hard' (complex and contentious) policy issues. But this has no doubt been reinforced by a loss of research capability elsewhere in the public service.

One likely cause of that is the blunt, across-the-board cutbacks in funding of government departments and agencies that have taken place over recent years in the name of 'efficiency'. These have tended to fall more heavily on research, it being seen as a more dispensable activity. Another may be the lack of what I'd call a 'hospitable' working environment for young economists seeking to make their mark on public policy.

Economists are often seen as mainly useful for generating numbers. Mike Finger, an American economist who worked with the World Bank for many years, has given a delightful account of a public hearing at the old US Tariff Commission in the early 1980s, in which the petitioning industry's flashy advocates ask their dowdy, hushpuppy-wearing economist, "How many chickens were there in Georgia in 1947, Dr. Brown?" (Finger 1984).

And David Henderson's depiction of the 'do it yourself economics' prevailing in the UK Civil Service, contains heartfelt insights about how the discipline is perceived (Henderson 1986). While science, engineering or accounting are seen as areas requiring trained specialists, economics is often regarded as something that anyone can pick up on the job (or on the run).

A good example of this is the confident assertion by non-economists of 'market failure' rationales for government intervention. Any deviations from perfect competition, or even failure of private firms to supply a good or service seen as desirable, can be cited as instances of 'market failure' justifying government action. There is much less recognition or acceptance of government failure of the costs of intervention, of concepts like optimism bias and the scope for unintended consequences. 


\section{The consultants}

Economic consultants and consulting firms are a third source of economic advice. The decline in economic capacity or capability within government has seen a parallel rise within these firms. Consulting firms have attracted many of Australia's best economists from academia and government. Indeed, in a number of cases government officials have left the public service to set them up. (I recall that the IMF, on one of its periodic visits to Australia some years ago, greatly offended senior Treasury officials by referring to Access Economics as the Treasury 'A Team').

While the rise of economic consultancies as a source of policy analysis and advice has brought benefits, there is a risk of governments becoming too dependent on such external expertise, at the expense of their own core policymaking capability. There is a related concern about the capacity of the public sector to effectively monitor and evaluate the work it commissions externally. Poor quality control invites poor quality. And that can be damaging when the advice relates to important areas of public policy.

\section{The journalists}

The final category of economic advice and analysis that I want to mention is the media. I think Australia has been well served over the years by its economic journalists. They have been few in number, but disproportionate in impact. Among other things, they have played a valuable role as translators and simplifiers of economic concepts and jargon.

They have been important in that respect not only in educating public opinion, but also political opinion. On a number of occasions it has transpired that a politician's understanding of one of our tomes has been acquired through newspapers, rather than from reading our work directly. That is not necessarily a problem if the reporting is accurate, though it has encouraged us to do better in summarising our own reports! The reality, though, is that in many cases such articles tend to be partial accounts at best, or actually get it wrong.

The facts are that, outside the small number of 'economist-journalists', the typical treatment in the press of economic ideas is not very good and often not even very accurate. That may partly reflect the nature of the medium. Newsworthiness and accurate information don't always coincide. This is particularly evident within the electronic media and especially television, where the 'grab' is not compatible with complexity, and there is a desire to identify adversaries and conflict to make a 'story'. 
Good economics is generally only 'news' when things have reached such a sorry state that basic economic logic appears novel. I like to think that that is why the Productivity Commission's reports can find themselves on the front page as headline news. However, I would not agree that the media has debauched our political or policy processes to the extent that Lindsay Tanner has recently described (Tanner 2011). I see it more as a reflection of these developments than the instigator; a mirror on reality, that hopefully may enable us to gain an understanding of the problems and the need to do better.

\section{The Bottom Line}

I've given a longish explanation for my very short initial answers to the two questions I was asked to address. My bottom line is that economics - good economics - can only flourish in the market for public policy if governments demand it. While this may not be the norm, Australia has benefited from creating policymaking environments in the past in which good economics has indeed flourished. It is timely to consider what may be needed to regain this in the future.

\section{References}

Alchian, A. and Allen, W. 1969, Exchange and Production: Theory in Use, Wadsworth, Belmont, California.

Banks, G. 2010, 'Evidence-Based Policy Making: What is it? How do we get it?' in Wanna, J. (ed.), Critical reflections on Australian Public Policy, Australian National University Press.

Finger, M. 1984, 'Remarks' presented at the NBER Conference on Research on Recent and Prospective US Trade Policy, Washington D.C., March.

Henderson, D. 1986, Innocence and Design: The Influence of Economic Ideas on Policy, Basil Blackwell, Oxford.

Knight, F. 1960, Intelligence and Democratic Action, Harvard University Press, Cambridge, Mass.

Moggridge, D. and Johnson, E. (eds) 1982, The Collected Writings of John Maynard Keynes, Vol 21, Macmillan, London.

Productivity Commission 2001, Structural Adjustment - Key Policy Issues, Commission Research Paper, Ausinfo, Canberra.

Tanner, L. 2011, Sideshow: Dumbing down democracy, Scribe Publications, Melbourne. 